\title{
Biopsychosocial and Institutional Factors Associated with Exclusive Breastfeeding among Working Mothers in Klaten, Central Java
}

\author{
Desi Ekawati'), Harsono Salimo²), Bhisma Murti 1) \\ ${ }^{1)}$ Masters Program in Public Heath, Sebelas Maret University \\ 2)Department of Pediatrics, Dr. Moewardi Hospital, Surakarta
}

\begin{abstract}
Background: Breast milk has an important role in health maintenance and survival of infants. It is acknowledged as the best food for infant. The World Health Organization has recommended exclusive breastfeeding (EBF) for infants until 6 months of age. However, many working mothers did not provide EBF to their infants. This study aimed to examine biopsychosocial and institutional factors associated with exclusive breastfeeding among working mothers, using health belief model and PRECEDE-PROCEED model.

Subjects and Method: This study was observational analytic with cross sectional design. It was conducted in Klaten District, Central Java, from March to April, 2017. A sample of 120 working mothers was selected for this study by simple random sampling. The dependent variable was exclusive breastfeeding. The independent variables were maternal education, perceived benefit, perceived barrier, self efficacy, family support, health personnel support, and availability of lactation room at workplace. The data were collected by a pre-tested questionnaire. Logistic regression was employed for data analysis.

Results: Maternal education $(\mathrm{OR}=4.2 ; 95 \% \mathrm{CI}=1.09$ to $11.51 ; \mathrm{p}=0.001)$, availability of lactation room at workplace $(\mathrm{OR}=4.11 ; 95 \% \mathrm{CI}=1.21$ to $14.29 ; \mathrm{p}=0.001)$, family support $(\mathrm{OR}=6.25 ; 95 \% \mathrm{CI}=$ 1.45 to $15.96 ; \mathrm{p}<0.001)$, health personnel support $(\mathrm{OR}=3.76 ; 95 \% \mathrm{CI}=1.43$ to $16.06 ; \mathrm{p}=0.002)$, perceived benefit $(\mathrm{OR}=2.30$; $95 \% \mathrm{CI}=1.09$ to $12.87 ; \mathrm{p}=0.044)$, self-efficacy $(\mathrm{OR}=3.57 ; 95 \% \mathrm{CI}=$ 1.21 to 14.29; $\mathrm{p}=0.002)$ had positive effect on EBF. Perceived barrier $(\mathrm{OR}=0.18 ; 95 \% \mathrm{CI}=0.64$ to $0.76 ; \mathrm{p}<0.001$ ) had negative effect on the provision of EBF.

Conclusion: Maternal education, availability of lactation room at workplace, family support, health personnel support, perceived benefit, self-efficacy have positive effect on EBF. Perceived barrier has negative effect on the provision of EBF among working mothers.
\end{abstract}

Keywords: biopsychosocial factors, exclusive breastfeeding, PRECEDE-PROCEED model, health belief model

\section{Correspondence:}

Desi Ekawati. Masters Program in Public Heath, Sebelas Maret University, Jl. Ir. Sutami 36 A, Surakarta, Central Java. Email: eccadesy@yahoo.com. Mobile: +6285725123320.

\section{BACKGROUND}

Breast milk has an important role in health maintenance and survival of infants. It is acknowledged as the best food for infants. Breast milk the ideal nutrition for infants since it contains the most appropriate nutrients to infants' needs, including antibodies that help the infants resist diseases (Febriyani, Rohsiwanto dan Hendarto 2014). In order to lower children's morbid- dity and mortality rate United Nations Children's Fund (UNICEF) and World Health Organization (WHO) has recommended to give infants only breast milk during the first six months of their life (Kementerian Kesehatan Republik Indonesia, 2015).

Government support exclusive breastfeeding among others by issuing Laws No. $36 / 2009$ regarding the health on article no 
128 verse 2 on the subject of breast milk provision, supports from family, health personnel, and regional government to mothers by providing time and facilities, and also the provision of lactation rooms at workplaces and public places.

National policy to exclusively giving breast milk for 6 months has been stipulated in Stipulation Letter of Health Minister No.450/Menkes/SK/IV/2004. The effort to support Exclusive Breastfeeding Program was the government of Klaten Regency especially Health Office of Klaten Regency had adopted Breastfeeding as the Primary Program of Klaten Regency. Performance of Exclusive Breastfeeding of Klaten Regency in 2014 was 81.4 \% (there were 6,716 infants exclusively fed with breast milk out of 8,249 infants of o- 6 months of age) (Dinkes Kabupaten Klaten 2015). In Klaten Regency there were still mothers who had not yet exclusively breastfed their infants. Some problems found regarding exclusive breastfeeding accomplishment, among others were breastfeeding mothers' lack of knowledge on the benefits of exclusive breastfeeding, insufficient support from family and health personnel, working environments that were not supporting exclusive breastfeeding program (Roekmito, 2014).

Working mothers who exclusively breastfeed their infants need sufficient knowledge, family support and the available lactation room/ lactation corner where mothers can express and store breast milk (IDAI, 2013). For working mothers, the short period of maternal leave leads to mothers should go working again before the period of exclusive breastfeeding is over. It disturbs the effort to practice exclusive breastfeeding. A study by Putri et al., (2015) revealed that there are only 5 mothers (8.1\%) who practicing exclusive breastfeeding among working mothers who work in factories (Depkes RI, 2005). Yet, working mothers can keep practicing exclusive breastfeeding for their infants by means of expressed breast milk (Susanti, 2011).

"Precede Proceed" developed by Green and Kreuter (2005), regarding factors affecting behavior among others are predisposing factors, reinforcing factors, enabling factors. The behavior of practicing exclusive breastfeeding are affected by several factors, such as prediposing factors (knowledge, attitude, values, culture and educational level), reinforcing factors (family support and health personnel support ), enabling factors (lactation room facility). Family support may increase mothers' self confidence during breastfeeding, and greatly contribute in the process of breastfeeding and giving breast milk. One of the determinant factors of mothers' accomplishment in practicing exclusive breastfeeding is family support (Anggorowati and Nuzulia, 2013). Factors that affect exclusive breastfeeding among others are age, education, income, occupation and antenatal care (Asemhagn, 2016).

Health Belief Model of Health behavior model (Rosenstock 1966 in Sulaeman, 2016) is a model that explains the existence of one's knowledge toward health threats and understanding toward suggested behaviors to prevent or overcome health problems. HBM theory consists of five primary elements namely individual perception toward a disease (perceived susceptibility), individual point of view toward the severity of a disease (perceived seriousness), individual perception toward the getting bigger obstacles (perceived threat), individual perception toward benefits and barrier and cues of action (self efficacy). Exclusive breastfeeding practice was affected by self efficacy, perceived benefits and barriers and it was supported by a study by Wardani, 
2012 on self efficacy in practicing exclusive breastfeeding.

\section{SUBJECTS AND METHOD \\ 1. Design of the Study \\ The study design used was analytic obser- vational, with cross sectional approach. Data collection was conducted in Wonosari I Community Health Center and Delanggu Community Health Center during March to April 2017}

\section{Population and Sampling Techni- que}

The population of the study was working breastfeeding mothers in Klaten Regency who had infants of 6 to 12 months of age. Sample selection was conducted by using simple random sampling to decide the proportion of subjects of the study. The sample of the study consisted of 120 subjects.

\section{Variables of the Study}

There were eight variables in the study, categorized as independent variables and dependent variable. The independent variables were family support, health personnel support, level of education, the availability of lactation room, perceived benefit, perceived barrier and self efficacy. The dependent variable was exclusive breastfeeding practice.

\section{Operation Definition of Variables}

Family support was defined as various forms of support given by members of family (husband, parents, parents in law, in laws, and others) to mothers toward exclusive breastfeeding practice.

Health personnel support was various forms of support given by health personnel (midwife, nurse, medical doctor) to mother toward exclusive breastfeeding practice.

Level of education was defined as the last formal education finished by a mother and earned a diploma. The availability of lactation room was defined as the availability of lactation room facility that sup- ported working mothers to provide breast milk.

Perceived benefit was defined as the effectiveness of maternal belief toward the exclusive breastfeeding practice behavior in order to reduce the risk on infants. Perceived barrier was defined as individual/ mother would experience barriers during exclusive breastfeeding practice for example in considering negative experience/ consequence, knowledge, cost, psychological/ physical matter. Self efficacy was defined as maternal belief on giving breast milk to her infant.

Exclusive breastfeeding practice was defined as giving breast milk to infant for six months without any other additional food and drink except drug and vitamin.

\section{Reliability Test}

Based on reliability test result on the itemtotal correlation it found the measurement of variables family support, health personnel support, educational level, availability of lactation room, perceived benefit, perceived barrier and self efficacy was $r$ counting $\geq 0.25$ and alpha Cronbach $\geq 0.75$, therefore all items of question were considered reliable.

\section{Data analysis}

Univariate analysis on quantitative data was conducted to present data characteristics and descriptive of variables of the study. Bivariate analysis was to analyze the effect of exogenous variables toward endogenous variable by using Chi-Square test. Multivariate analysis with logistic regression analysis was used to predict dependent variable out of several independent variables.

\section{RESULT}

Dimensional characteristics of 120 study subjects from 3 schools observed based on age and maternal education. Table 1 showed that out of 120 study subjects there were 
Journal of Health Promotion and Behavior (2017), 2(3): 197-206

https://doi.org/thejhpb.2016.02.03.01

$11.7 \%$ who were $<20$ years of age, $62.5 \%$ were between $20-35$ years of age and $25.8 \%$ were $\geq 35$ years of age. Educational level $30.8 \%$ were associate/ bachelor degree,

Table 1. Characteristics of study subjects

\begin{tabular}{clcc}
\hline \multicolumn{1}{c}{ Characteristics } & \multicolumn{1}{c}{ Category } & N & \% \\
\hline Age (years) & $<20$ years & 14 & 11.7 \\
& 20-35 years & 75 & 62.5 \\
Maternal education & $\geq 35$ years & 31 & 25.8 \\
& Primary/Secondary & 31 & 25.8 \\
& School & & \\
& High & 52 & 43.4 \\
& School/Vocational & & \\
& High School & & 30.8 \\
\hline & Associate/ Bachelor & 37 & \\
& Degree & 37 &
\end{tabular}

The result of descriptive statistics of continuous data by means of family support, health personnel support, educational level, availability of lactation room, per-
43.4\% were high school/vocational high school, $25.8 \%$ were secondary/primary school.

Table 2. Univariate analysis of variables of the study

\begin{tabular}{lccccc}
\hline \multicolumn{1}{c}{ Variables } & n & Mean & SD & Min. & Max. \\
\hline Educational level & 120 & 1.74 & 0.44 & 1 & 2 \\
Availability of lactation room & 120 & 1.56 & 0.5 & 1 & 2 \\
Family support & 120 & 43.53 & 5.79 & 27 & 58 \\
Health personnel support & 120 & 39.68 & 6.71 & 25 & 55 \\
Perceived benefit & 120 & 53.31 & 4.83 & 33 & 63 \\
Perceived barrier & 120 & 40.75 & 4.62 & 30 & 54 \\
Self efficacy & 120 & 55.71 & 7.03 & 35 & 70 \\
Exclusive breastfeeding practice & 120 & 1.73 & 0.44 & 1 & 2 \\
\hline
\end{tabular}

Table 2 showed that each variable had relatively small data variation. Mean represented average value, whereas standard deviation (SD) represented how varied that data was. Small amount of SD was an indication that the data was representative.

Table 3 showed that education $(\mathrm{OR}=$ 4.2; $95 \% \mathrm{CI}=1.79$ to $9.85 ; \mathrm{p}=0.001)$, availability of lactation room $(\mathrm{OR}=4.11 ; 95 \% \mathrm{CI}$ $=1.74$ to $9.72 ; \mathrm{p}=0.001)$, family support $(\mathrm{OR}=6.25 ; 95 \% \mathrm{CI}=2.56$ to $15.27 ; \mathrm{p}$ $<0.001$ ), health personnel support (OR= $3.76 ; 95 \% \mathrm{CI}=1.61$ to $8.78 ; \mathrm{p}=0.002$ ), perceived benefit $(\mathrm{OR}=2.30 ; 95 \% \mathrm{CI}=1.01$ to $5.25 ; \mathrm{p}=0.044)$, self efficacy $(\mathrm{OR}=3.57$; ceived benefit, perceived barrier, self efficacy, and exclusive breastfeeding practice could be observed in Table 2 . 
From Table 4 it was observed that education, lactation room, family support, health personnel support, perceived bene- fit, perceived barrier, and self efficacy affected exclusive breastfeeding practice.

Table 3. Chi Square bivariate analysis on variables level of education, availability of lactation room, family support, health personnel support, perceived benefit, perceived barrier, self efficacy, and exclusive breastfeeding practice

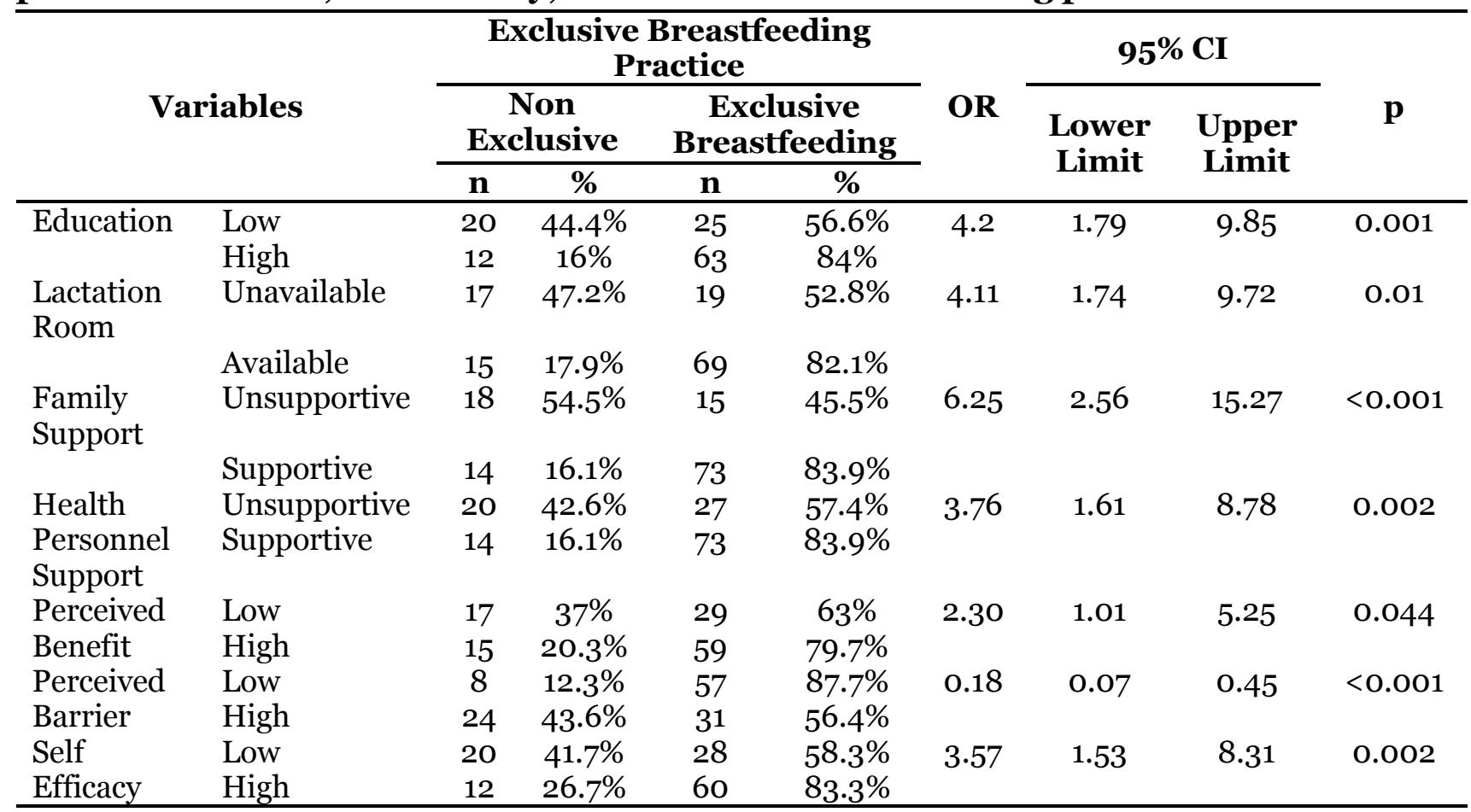

There was a positive and significant association between maternal education exclusive breastfeeding practice it indicated mothers with high educational level had 3 times higher possibility to practice exclusive breastfeeding compared to mothers with low educational level (OR=3.55; 95\% $\mathrm{CI}=1.09$ to $11.51 ; \mathrm{p}=0.035)$.

Table 4. Result of logistic regression on level of education, availability of lactation room, family support, health personnel support, perceived benefit, perceived barrier, self efficacy in exclusive breastfeeding practice.

\begin{tabular}{|c|c|c|c|c|}
\hline \multirow{2}{*}{ Variables } & \multirow{2}{*}{ OR } & \multicolumn{2}{|c|}{$95 \% \mathrm{CI}$} & \multirow[b]{2}{*}{$\mathbf{p}$} \\
\hline & & Lower Limit & Upper Limit & \\
\hline Education & 3.55 & 1.09 & 11.51 & 0.035 \\
\hline Lactation Room & 4.15 & 1.21 & 14.29 & 0.023 \\
\hline Family Support & 4.82 & 1.45 & 15.96 & 0.010 \\
\hline Health Personnel Support & 4.79 & 1.43 & 16.06 & 0.011 \\
\hline Perceived Benefit & 3.7 & 1.09 & 12.87 & 0.036 \\
\hline Perceived Barrier & 0.22 & 0.64 & 0.76 & 0.017 \\
\hline Self Efficacy & 4.13 & 1.21 & 14.07 & 0.023 \\
\hline $\mathrm{N}$ observation & 120 & & & \\
\hline-2 log likehood & 80.30 & & & \\
\hline $\begin{array}{l}\text { Nagelkerke R Square } \\
p=0.005\end{array}$ & $56 \%$ & & & \\
\hline
\end{tabular}


Journal of Health Promotion and Behavior (2017), 2(3): 197-206

https://doi.org/thejhpb.2016.02.03.01

There was a positive and significant association between the availability of lactation room and exclusive breastfeeding practice. It indicated that working mothers with lactation room available at their workplace had 4 times higher possibility to practice exclusive breastfeeding compared to working mothers without lactation room available at workplace $(\mathrm{OR}=4.15 ; 95 \% \mathrm{CI}=$ 1.21 to $14.29 ; \mathrm{p}=0.023$ ).

There was a positive and significant association family support and exclusive breastfeeding practice. It indicated that mothers with supportive family had 4 times higher possibility to practice exclusive breastfeeding compared to mothers with unsupportive family $(\mathrm{OR}=4.82 ; 95 \% \mathrm{CI}=$ 1.45 to $15.96 ; p=0.010$ ).

There was a positive and significant association between health personnel support and exclusive breastfeeding practice. It indicated that mothers with supportive health personnel had 4 times higher possibility to practice exclusive breastfeeding compared to mothers with unsupportive health personnel $(\mathrm{OR}=4.79 ; 95 \% \mathrm{CI}=1.43$ to $16.06 ; \mathrm{p}=0.011$ ).

There was a positive and significant association between perceived benefit and exclusive breastfeeding practice. It indicated that mothers with high perceived benefit had 3 times higher possibility to practice exclusive breastfeeding compared to mothers with low perceived benefit $(\mathrm{OR}=$ $3.7 ; 95 \% \mathrm{CI}=1.09$ to $12.87 ; \mathrm{p}=0.036$ ).

There was a negative and significant association between perceived barrier and exclusive breastfeeding practice. It indicated that mothers with high perceived barrier had $1 / 5$ times lower possibility to practice exclusive breastfeeding $(\mathrm{OR}=0.22$; $95 \% \mathrm{CI}=0.64$ to $0.75 ; \mathrm{p}=0.017$ ).

There was a positive and significant association between self efficacy and exclusive breastfeeding practice. It indicated that mothers with high self efficacy had 4 times higher possibility to practice exclusive breastfeeding compared to mothers with low self efficacy (OR= $4.13 ; 95 \% \mathrm{CI}=1.21$ to 14.07; $\mathrm{p}=0.023$ ).

\section{DISCUSSION \\ 1. The association of family support and exclusive breastfeeding practice}

Result of logistic regression analysis of the study showed that there was a positive association and statistically significant between family support and exclusive breastfeeding practice. The result of analysis also indicated that mothers who were supported by their family were able to improve her exclusive breastfeeding practice 4 times higher than mothers who were not supported by her family.

The result of the study is in accordance with a study by Rahayu dan Apriningrum (2014) which stated that insufficient family support is one of the reasons for failure of exclusive breastfeeding practice. Family support is a resource of assistance for the accomplishment of exclusive breastfeeding practice. The role of family, among other is monitoring maternal health in term of the needs for nutritious food intake, rest, and consistency to practice exclusive breastfeeding although the mother works.

The result of study is in accordance with a study conducted by Mannion et al (2013) that family support greatly affects the accomplishment of exclusive breastfeeding practice, such as support from husbands in which mothers will feel more capable and confident in breastfeed their infant when they find their husbands support well by means of verbal support as well as active involvement in mothers' breastfeeding activity. Husbands and family support can be verbally as well as by means of 
actions, such as helping mothers with their position during breastfeeding, helping to change diapers/ nappy or helping mothers while they were busy breastfeed the infants. Husbands or family support may increase mothers' self confidence in breastfeeding their infants and may improve exclusive breastfeeding practice.

\section{The association of health person- nel support and exclusive breastfeed- ing practice}

Result of logistic regression analysis of the study showed that there was a positive association and statistically significant between health personnel support and exclusive breastfeeding practice. The result of analysis also indicated that mothers who were supported by health personnel were able to improve her exclusive breastfeeding practice 4 times higher than mothers who were not supported by her family.

The result of the study is supported by a study conducted by Damanik et al., (2015) on the subject of health personnel support may help mothers to give breast milk well. The conclusion of the study is it takes motivation provision, infrastructure improvement, periodic monitoring and evaluation to encourage breastfeeding counseling activities in order to promote the accomplishment of exclusive breastfeeding program.

The study is in accordance with a study conducted by Widdelrita and Mohanistenaga (2015) about the role of health personnel toward exclusive breastfeeding, that health personnel will attempt to improve clients' well being by influencing their behavior. Health personnel support in exclusive breastfeeding practice for mothers is by improving maternal behavior both in exclusively breastfeed as well as breastfeed their infants for 2 years and helping mothers in solving barriers and problems related to breastfeeding.

\section{The association of maternal educa- tion and exclusive breastfeeding practice}

Result of logistic regression analysis of the study showed that there was a positive association and statistically significant between educational level and exclusive breastfeeding practice. The result of analysis also indicated that mothers who had high level of education were able to improve her exclusive breastfeeding practice 3 times higher than mothers who had low level of education family.

It is in accordance with Depkes RI (2005) that conveys that support given by health personnel may generate mothers' self confidence to willingly breastfeed their infants. Information given by health personnel about breast care during pregnancy, period of breastfeeding, benefit of breastfeeding, early breastfeeding initiation, may promote the accomplishment of exclusive breastfeeding practice.

The result of the study is in accordance with a study conducted by Onah et al., (2014). The study represents the factors of exclusive breastfeeding practice. The conclusion of the study is maternal education, social economy, delivery methods, and the first breastfeeding are factors that are important in breastfeeding. It is concluded that with high knowledge and education, the role of health personnel, and policy in the workplace may encourage mothers to breastfeed their infants.

\section{The association of availability and exclusive breastfeeding practice}

Result of logistic regression analysis of the study showed that there was a positive association and statistically significant between availability of lactation room and exclusive breastfeeding practice. The result of analysis also indicated that working mothers who were equipped with lactation room at workplaces were able to improve 
her exclusive breastfeeding practice 4 times higher than mothers who were not equipped with lactation room at workplaces.

The study is in accordance with a study conducted by Amin et al, (2011) the conclusion of the study is factors that influence working mothers to quit breastfeeding their infants or do not exclusively breastfeed for six months.

\section{The association of perceived bene- fit of exclusive breastfeeding and ex- clusive breastfeeding practice}

Result of logistic regression analysis of the study showed that there was a positive association and statistically significant between perceived benefit and exclusive breastfeeding practice. The result of analysis also indicated that mother with high perceived benefit were able to improve her exclusive breastfeeding practice 3 times higher than mothers with low perceived benefit.

The result of the study is in accordance with a study conducted by Pratiwi (2014) on the subjects of the husband support and perception toward behavior of exclusive breastfeeding practice with a result there is a positive association between mothers' perception and exclusive breastfeeding practice. Good perception or perceived benefit about exclusive breastfeeding is affected by other factors such as education, age, and health personnel support.

\section{The association of perceived barrier and exclusive breastfeeding practice}

Result of logistic regression analysis of the study showed that there was a negative association however it is statistically significant between perceived barrier and exclusive breastfeeding practice. The result of analysis also indicated that mother with high perceived barrier may reduce her exclusive breastfeeding practice by $1 / 5$ times than mothers with low perceived barrier.

The study is in accordance with a study conducted by Fikawati S dan Syafiq A (2012) on perceived breastfeeding adequacy. The study indicated that perceived insufficient milk supply that influence self confidence to breastfeed becoming one of the main reasons of breastfeeding failure.

The study is in accordance with a study conducted by Diji et al (2017) about challenges and barriers toward exclusive breastfeeding practice. The result of the study is that mothers face various challenges both in level of individual, society, and the stakeholders.

\section{The association of self efficacy and exclusive breastfeeding practice}

Result of logistic regression analysis of the study showed that there was a positive association and statistically significant between self efficacy and exclusive breastfeeding practice. The result of analysis also indicated that mother with high self efficacy were able to improve her exclusive breastfeeding practice 4 times higher than mothers with low self efficacy.

The result of the study was in accordance with a study Khoiriyah (2014). The study aims to know the association between self efficacy and husband support toward exclusive breastfeeding practice, the result is that high self efficacy and strong husband support may increase the possibility of exclusive breastfeeding practice.

\section{REFERENCE}

Amin RM, Said ZM, Sutan R, Syah SA, Darus A, Syamsuddin K (2011). Work related determinants of breastfeeding discontinuation among employed mothers in Malaysia. International Breastfeeding Journal 2011.

Anggorowat, Nuzulia F (2013). Hubungan antara Dukungan Keluarga dengan 
Pemberian ASI Eksklusif pada Bayi di Desa Bebengan Kecamatan Boja Kabupaten Kendal. Departemen Keperawatan Maternitas dan Anak, Jurusan Keperawatan Fakultas Kedokteran Universitas Diponegoro, Semarang.

Asemhagn (2016). Determinants of exclusive breastfeeding practices among mothers in azezo district, northwest Ethiopia. International Breastfeeding Journal.

Damanik R, Rahmawati W, Soemardini (2015). Hambatan Kinerja Konselor Menyusui dalam Meningkatkan Cakupan Pemberian ASI Eksklusif di Kota Kupang. Indonesian Journal of Human Nutrition, 2(1): 1 - 10.

Depkes RI. (2005). Kebijakan Departemen Kesehatan Tentang Peningkatan Pemberian Air Susu Ibu (ASI). Jakarta.

Diji AK, Bam V, Asante E, Lomotey AY, Yeboah S, and Owusu HA (2017) Challenges and predictors of exclusive breastfeeding among mothers attending the child welfare clinic at a regional hospital in Ghana: a descriptive crosssectional study. International Breastfeeding Journal (2017) 12:13

Dinkes Kabupaten Klaten. (2015). Profil Kesehatan Kabupaten Klaten

Febriyani R, Rohsiwanto R, Hendarto A (2014). Faktor-Faktor yang Mempengaruhi Pemberian ASI Eksklusif Pada bayi cukup bulan yang dilakukan Inisiasi Menyusu Dini. Sari Pediatri, 15(6).

Fikawati S, Syafiq A (2012). Status Gizi Ibu dan Persepsi Ketidakcukupan Air Susu Ibu. Kesmas, Jurnal Kesehatan Masyarakat Nasional 6 (6) Juni 2012.

IDAI (2013). ASI Eksklusif pada Ibu yang Bekerja. [online] IDAI.
Kementerian Kesehatan Republik Indonesia. (2015). Situasi dan analisis ASI Eksklusif. Jakarta: Kemenkes RI.

Khoiriyah A (2014). Hubungan antara efikasi diri dan dukungan suami dalam menyusui dengan pemeberian ASI eksklusif di wilayah kerja puskesmas urangagung Sidoharjo. Tesis. UNS .

Mannion C, Hobbs A, McDonald A, Tough $S$ (2013) Maternal perceptions of partner support during breastfeeding. International Breastfeeding Journal. 8:4.

Onah (2014) Infant feeding practices and maternal socio-demographic factors that influence practice of exclusive breastfeeding among mothers in Nnewi South-East Nigeria: a crosssectional and analytical study. International Breastfeeding Journal.

Pratiwi MLA, (2014). Pengaruh Dukungan suami dan persepsi ibu terhadap perilaku pemberian ASI eklsusif. Tesis. UNS di akses 21 Mei 2017.

Rahayu S, Apriningrum N (2014). FaktorFaktor yang Berhubungan Pemberian ASI Eksklusif dapa Karyawati UNSIKA. Jurnal Ilmiah Solusi. 1(1).

Roekminto R (2014). Upaya Peningkatan Program ASI Eksklusif di Kabupaten Klaten. Dinkes Kabupaten Klaten: Klaten.

Sulaeman ES (2016). Promosi Kesehatan Teori dan Implementasi di Indonesia. UNS pers. Surakarta.

Susanti N (2011). Peran Ibu Menyusui yang Bekerja dalam Pemberian ASI eksklusif Pada Bayinya, Egalita Jurnal Kesetaraan dan Keadilan Gender, 6(2):165-176.

Widdelrita M (2015). Peran petugas kesehatan dan status pekerjaan ibu dengan pemberian ASI eksklusif. Jumal Kesehatan masyarakat, 8(1). 